\title{
ENGEL'S APPROACH AS A TOOL FOR ESTIMATING CONSUMER BEHAVIOUR
}

\author{
Renata Benda-Prokeinová, Kamil Dobeš, Ladislav Mura, \\ Ján Buleca
}

\section{Introduction}

Consumer's preferences and wealth (income, resources) are viewed as exogenous quantities in the neoclassical theory. Methodological individualism, rational behaviour, equilibrium and perfect information of consumer are the further features of this concept.

Simple precautions are the necessary condition for model application. Methodological individualism assume, that the principles of the individual subjects behaviour are the most important determining factors of the model functioning. These subjects act according to maximizing of the total utility in the given conditions. The concept of equilibrium is static. The perfect information precondition need not to be necessary fulfilled because the contemporary concepts of the consumer's behaviour function in the conditions of risk and uncertainty (Aguirre Sotelo \& Block, 2014). Institutional concepts of consumption are derived from the T. Veblen's theory of the leisure class consumption (Grzega, 2015). The preferences are influenced by the position of the consumer subject in the social hierarchy and by activity of firms. According to J. Galbraith, firms can partially create the desires of the consumers. Not only the preferences, resources, and the individual behaviour, but also social institutions are important factors of consumption in the institutionalism concepts. Consumption is viewed also as a social behaviour. Psychological aspects of the consumer subjects' behaviour are also important. In the modern concept of consumption, there must be viewed all aspects of it. Consumer behaviour is based on the decision-making of individuals spending their own resources (i.e. time, money and efforts) in order to obtain the items associated with consumption Novotný and Duspiva (2014); Horáková (2015). This form of behaviour involves the reasons why, when, where, how often and what people buy, how often they use the purchased items, how they evaluate them after the purchase, and in which way these factors influence their future purchases Šrédl, Soukup and Severová (2013); Wanninayake W.M.C. Bandara (2014).

Marketing is so much more than creating a catchy phrase or a jingle people will sing for days. Understanding consumer behavior is a vital aspect of marketing. Consumer behavior is according to Stávková et al. (2006) the study of how people make decisions about what they buy, want, need or act in regards to a product, service, or company. This issue was studied by Krishna and Schwarz (2014) in detail and in relation to psychology aspects. It is critical to understand consumer behavior to know how potential customers will respond to a new product or service (Bačík, Gavurová, \& Fedorko, 2015). It also helps companies identify opportunities that are not currently met (Gavurová, Vagasova, \& Kovac, 2016). Through research and observation, several models have been developed that help further explain why consumers make decisions, including black box, personal variables, and complex models. The black-box model is based on external stimulus-response, meaning something triggers the consumer to make buying decisions that are influenced by many factors, including marketing messages, sampling, product availability, promotions, and price (Michalski, 2008; Andrejovska \& Banociova, 2014; Raisova \& Durcova, 2014).

When influenced by the personal-variable model, consumers make decisions based on internal factors. These internal factors may include personal opinions, belief systems, values, traditions, goals, or any other internal motivator (Dúbravská, Mura, Kotulič, \& Novotný, 2015). The complex model of consumer behavior considers both internal and external variables. 
Human food choice is a complex phenomenon influenced by a wide range of factors (Hes et al., 2008; Czarniewski, 2014). The theory of planned behaviour offers a means for trying to understand the roles of some of these factors. Evidence will be presented for the inclusion of measures of self-identity and moral obligation. Problems with the measurement of perceived control and possible means for overcoming them will also be discussed.

The choice of foods is an area of concern for many people involved in the production and distribution of foods, and for those concerned with nutrition and health education. Relatively little is known about how and why people choose the foods that constitute their diets or about how their choices can be influenced in an effective way.

Like any complex human behaviour, food choice will be influenced by many factors. There are a number of models in the literature, which seek to delineate the effects of likely influences. Piqueras-Fiszman and Jaeger (2016) concentrate on the question why consumers associate certain emotions with food/beverages and meal occasions. This topic is important as people's food-related behaviour and attitudes are shaped by these associations. However, many such models are simply catalogues of the likely influences. Few of them present any indication of the likely mechanisms of action of the multitude of factors identified, nor do they quantify the relative importance of factors or allow any quantitative tests which are predictive of food choice. Although such models can be useful in pointing to the variables to consider in studies in this area, they do not provide a framework for quantitative modelling of food choice behaviour.

The factors influencing food choice are categorized as those related to the food, to the person making the choice and to the external economic and social environment within which the choice is made (Hildenbrand, 1994; Virglerova, Dobes, \& Vojtovic, 2016). Some chemical and physical properties of the food will be perceived by the person in terms of sensory attributes, e.g. flavour, texture or appearance. However, perceiving these sensory attributes in a particular food does not necessarily mean that a person will or will not choose to consume that food. It is the person's liking for that attribute in that particular food which will determine whether or not the food is chosen.
Other components in the foods will have effects upon the person, e.g. reducing hunger, and the learning of the association between the sensory attributes of a food and its consequences appears to be a major mechanism by which preferences develop. Marketing and economic variables, as well as social, cultural, religious or demographic factors are also likely to be very important.

This paper applies a behavioral approach to consumption to connect differences in satiation patterns between innate needs with systematic changes in consumption expenditures when income rises. It is conjectured that, at the level of aggregate expenditure data, these differences translate into different income elasticities of demand for groups of goods and services that are likely to be consumed to serve those needs. This way, it should be able to explain a good deal of the differences in the shapes of Engel curves of the underlying goods and services (Lewbel, 2008; Lades, 2013).

We illustrate in the paper the technique of Engel curve computation on the household's income and expenditure data originated from the Statistical Office of the Slovak Republic. Results of the method will be presented as a set of elasticities, which provide deeper knowledge about consumer's behavior of the Slovak households.

\section{Theoretical Background of Consumer Behavior}

Factors that influence the purchasing behavior of consumers are very significant for businesses, because based on these factors, it is possible to focus the trade policy, which then could lead to better business results (e.g. an increase in sales volume, market share, distribution of a portfolio of clients, etc.). Every human is a consumer, and for the other consumers represents the key factors that influence their purchasing behaviour. Theory and practice nowadays lacks greater links between businesses and consumers, based on segmentation by appropriate segmentation criteria. More detailed description of segmentation criteria highlights (Koudelka, 2005). In many areas of law such connections, including research that would facilitate company decisions is inadequate. There are a number of research projects related to lifestyle, dress, smoking, eating (Šoltés \& Gavurová, 2014), but research including models and factors 
influencing purchasing behaviour consumers in many manufacturing industries is missing. The issue of purchasing behavior of consumers was discussed by several prominent authors (Kotler \& Armstrong, 2004; Solomon, Marshall, \& Stuart 2006; Stávková et al., 2006; and others). The assumption is that the consumer will act rationally and will maximize the overall benefit that is associated with a combination of goods and services that accompany the product. According to Hes et al. (2008), however, it is limited by the consumer when making decisions, especially by the financial resources. In many fields linking businesses and consumers, including research their behavior that would facilitate decision of company management is insufficient. One of other approaches to the analysis of consumer behaviour is also monitoring behaviour when there is a change in information cost. This may vary across consumers, which is the case when consumers who search for information are "bounded rational" - making random errors due to limited attention (Manzini \& Mariotti, 2014) or "rationally inattentive" - optimally allocate attention (Matějka \& McKay, 2015). Following these approaches, it is also important to study how to optimally inform a consumer about the valuations for multiple goods when a consumer can learn about fewer goods than he/she can consume (Saak, 2016).

Market orientation is an approach based on marketing conception, introduced by Drucker (1954). Although the principle of market orientation has been known for sixty years, detailed analysis only began at the beginning of the 1990s. In 1990, the Journal of Marketing published the results of two studies sponsored by the Marketing Science Institute. Those studies were made by Kohli and Jaworski (1990) and by Narver and Slater (1990). These two pieces of research had a substantial impact on the formation of a new approach to marketing and subsequent studies on market orientation and took the initial steps towards creating a definition of market orientation. The definition of Kohli and Jaworski (1990) was totally different to those by Narver and Slater (1990). The definition by Kohli and Jaworski (1990) perceives market orientation as an implementation, namely as an instrument for strategic decision-making. Alternatively, the definition of Narver and Slater (1990) perceives market orientation from a business learning and corporate culture point of view Novotný and Duspiva (2014).

Other approach by Šrédl, Soukup and Severová (2013) and by Peréz et al. (2013) were applied in modern market economy where the supply exceeds demand, and the importance of the "consumer's behaviour in the market analysis" continuously increases. Consumer's preferences are viewed as exogenous variables in a neoclassical theory. They are not explained in a framework of the concept but are viewed as given ones. Heikkinen (2015) studied decline and growth in a dynamic equilibrium model with preference heterogeneity. Simulations suggest that decline triggered by voluntary simplicity increases equilibrium welfare under externalities in consumption and leisure. Methodological individualism, rational behavior, equilibrium, and perfect information about the consumers are the next features of this concept. Simple precautions are a necessary condition for the model application. Methodological individualism means that principles of individual subjects behaviour are the most important determining factors of model functioning. These subjects abide by the principle of total utility maximizing in given conditions. The concept of equilibrium is static. Perfect information precautions doesn't need to be necessarily fulfilled, because contemporary concepts of consumer's behavior function in the conditions of risk and uncertainty. Institutional concepts of consumption are derived from Veblen's theory of leisure class consumption (Herrnstein, 1997). There is also a strong marketing influence. Subramanyam and Kumaraswamy (1981) consider the effect of marketing policies and conditions on demand. It is worth to mention a few smart marketing tools influencing customer behaviour. Online customer behavior is a new phenomenon and it is a very important case for firm's marketing (Rypakova, Moravcikova, \& Krizanova, 2015). Kramolis and Kopeckova (2014) deal with this kind of smart marketing tool (Product placement) which clearly influences customers. Indeed, there are not only luxury goods, (Kramolis \& Drabkova, 2012) which are promoted by means of product placement. This marketing activity has a simple purpose - to connect brands with appropriate entertainment partners to maximize brand relevance -- which leads to strengthening consumers' attitudes to promoted products. This smart marketing whisperings can build the preferences wanted. 
Moreover, preferences are influenced by the position of a consumer subject in the social hierarchy. Not only preferences, resources and individual behavior, but also social institutions represent the important factors of consumption in institutionalists' concepts. Consumption is also viewed as social behavior. Ultimately psychological aspects of consumer subject's behavior are also important. The contemporary relationship between brand personality and consumer personality has become a researched issue in recent years and it was studied by Banerjee (2016). The author's result shows buying decision, personalities of promoted products and corporate brands influencing consumers' preferences.

Engel curves describe the change of expenditure (or demand) for different commodities as a function of income. It is common to speak about "cross-section Engel curves" if one considers expenditures of a population of households (for example, all households in a large countries (Becerra Alonso, Androniceanu, \& Georgescu, 2016)) rather than single individuals. Since the work of Engel (1857), cross-section Engel function has been a major research in economies and econometrics. Engel curves have been extensively studied to establish empirical relationships between expenditure and income. Engel's law states, that the budget shares for the commodity food decrease with an income. Generally, Engel functions can be used to classify commodities into luxuries, necessities and inferior goods. The most known classical study of cross-section Engel curves is that of Prais and Houthakker (1955). Important objective is the determination of budget elasticities for different commodities from the corresponding Engel curves.

In demand analysis, the structure of crosssection Engel curves has been exploited to build up demand system. Working (1943) proposes the parametric model $m(x)=\theta 1 x+$ $\theta 2 x \log x$ for the cross-section Engel function $\mathrm{m}(\mathrm{x})$ of some commodity. Here, $\mathrm{x}$ denotes income, the $\theta 1, \theta 2$ are unknown parameters, which are to be estimated from given data. Deaton and Muellbauer (1980) consider this model as an important motivation of their famous „AIDS - almost ideal demand system“. When doing the analysis of food demand, the model of AIDS was used in works of Benda Prokeinova and Hanova (2016), Ulubasoglu et al. (2016) and Hayat et al. (2016). The finding of Lewbel (1993), telling that a better parametric model might be written in the form $m(x)=\theta 1 x+\theta 2 x \log x+\theta 3 x(\log x)^{2}$ is often interpreted as a justification of the quadratic almost ideal demand system of Blundell et al. (1993), which generalizes the results of Deaton and Muellbauer (1980). These approaches are based on the idea of recoverability of individual behavior from aggregate data. In the present context this corresponds to the assumption that the structure of cross-section Engel curves reflects the structure of individual ones. The same argument was used by Härdle and Jerison (1991), where a certain variance of estimated cross-section Engel curves over time were used to draw conclusions on individual behavior.

Engel curves also play a role in the theoretical economics. Hildenbrand (1994), and Kahneman (1997) provides conditions on the structure of these curves which ensure the law of demand.

There is thus strong empirical and theoretical interest to analyze the cross-section Engel function of real populations. A prerequisite of any economic interpretation is a reasonable estimation of these curves from given crosssection data about household expenditures and income.

Statistically, cross-section Engel curves are regression function, $m(x)$ equals to the conditional expectation of expenditure for a commodity given the income level $x$. The classical approaches in regression analysis are based on parametric models, i.e. $m(x)=g(x, \theta)$ with a known function $g$ and an unknown parameter $\theta$. The vast majority of studies of Engel curves are based on such parametric models. Apart from the Working model, there are many further parametric approaches (double logarithmic, semilogarithmic, etc.). In any parametric model the functional shape of the estimate is already given by an assumption. The quality of the resulting estimator depends heavily on the correctness of this specification. If a model is correct, good estimators of the parameters and the curves can usually be obtained. However, if the model is poorly specified, the resulting estimator is not even consistent. Since the economic theory doesn't yield any information about a correct parametric model, there is thus reason to consider the alternative approaches. 


\section{Material and Methods}

According to Friedman's hypothesis the consumption of individuals or households depends on $p$ income, it does not depend on the current income of economic unit as Keynes insisted. Permanent income can be explained as an average income, which an individual expects to earn during his life using his labor and capital. Šimsová and Reissová (2016) deal with the topic of expected income of selected groups of inhabitants, e.g. university students. According to Gombos, Kiss and Zvara (2016) it depends on household welfare (human capital, education, health included), interest rate, and expected job vacations.

The similar approach was described by Engel. Engel curves describe the change of expenditure (or demand) for different commodities as a function of income from the theoretical viewpoint.

\subsection{Engel Curves and the Income Elasticity of Demand}

The general connection between the shape of an Engel curve and the income elasticity of the respective good can easily be illustrated. If an Engel curve for good $i$ is expressed in terms of the expenditures qi spent on i depending on the households' income $y$, the slope of the fitted curve dqi/dy can indirectly be used to derive i's income elasticity of demand. As a good's income elasticity is defined by the relative change in qi (dqi/qi) divided by the relative change in $y$ (dy/y), it can be estimated by regressing logarithm of qi on logarithm of y Lewbel (2008).

Using expenditure shares (wi=qi/ywi=qi/y), instead of the expenditures spent on $i$, facilitates more directly an inference of the income elasticity of demand from the curve's slope. While an increasing slope represents more than proportional expenditures, thus luxuries, a decreasing slope points to less than proportional expenditures with rising income, i.e., necessities. Although Engel curves usually show considerable nonlinearities Lewbel (2008), budget share Engel curves facilitate to readily observe the income elasticity of demand for the underlying group of goods and services.

\subsection{A Motivational Approach to Consumer Behavior}

Engel's approach to consumption never solely focused on food expenditures. In fact, Engel's original contribution was meant to determine and measure household welfare by Chai and Moneta (2010). He started by categorizing expenditure items according to the underlying "wants" they satisfy. The importance of these wants was subsequently assessed by the empirically derived expenditure patterns. Engel's work thus essentially focused on a behavioral foundation of the necessity-luxury taxonomy. In a revised version of his original contribution, Engel (1895) made even more explicit, that the motivation of human action, and thus also consumption behavior, is rooted in the satisfaction of universally-shared needs (Chai \& Moneta, 2010).

To build upon Engel's legacy, this paper enriches the classification of needs with current scientific knowledge on the nature of consumer needs and how they are satisfied. However, motivational underpinnings of economic behavior in general and consumer behavior in particular are rarely addressed in economics. Among the existing works, two different explanatory approaches were identified by Witt (2010). While in the utilitarian hedonic approach the explanation refers to the motives of seeking pleasure and avoiding pain, nonhedonistic variants focused on the motivating power that deprived needs and wants have for consumption activities.

This paper closely connects to the latter approach. A behavioral-need basedinterpretation of the consumption motivation was offered by Witt $(2001 ; 2010)$ to actually theoretically explain the necessity-luxury distinction that becomes visible through the shape of Engel curves. The theory postulates an intimate relationship between human biological and cultural evolution in the sense that cultural development is based upon as well as constrained by innate behavioral dispositions and cognitive learning abilities, which have emerged during human phylogeny. Hence, the theory focuses on the explanation of long-run economic change from a biological and psychological perspective (Witt, 2008).

The theory of the learning consumer (Witt, 2001 ; 2010) emphasizes the role of human needs as ultimate motives of consumption behavior. The theory distinguishes between genetically determined-innate-needs and both culture and socialization specific acquired wants, that result from processes of associative learning (classical and operant conditioning) 
and social-cognitive learning. The theory holds the attempt to relieve or reduce deprivation of a limited number of innate needs, consequently an increase in satiation level of these needs, is one major motivation to consume. Deprivation is thus seen to intrinsically motivate consumers to act which creates a rewarding experience.

Needs are the contingencies under which deprivation occurs. Although needs can be manifold, in this context only the subset of universally-shared "basic" needs i relevant. Among these are that for sleep, for something to drink, for something to eat, for maintaining body temperature, for physical activity, for status recognition, or for sensory arousal Witt (2011).

An important characteristic of these needs is that their satisfaction by an action effects a primary reinforcement in the sense of instrumental or operant conditioning (Staddon \& Cerutti, 2003). This, of course, has implications for the allocation of resources. Imagine individuals to be equipped with a fixed set of innate needs that show different need deprivation states. If individuals allocate their behavior to obtain a reduction of their deprivation states, the likelihood that a particular activity is chosen over another one depends on its relative contribution to reducing deprivation. Individuals are accordingly assumed to shift their behavior to those alternatives which provide the highest average reward. The allocation of income to consumption categories results as proportional to the corresponding need deprivation states. Under reinforcement learning, the frequency distribution over actions converges to a state satisfying the so called "matching law" Herrnstein (1997), which seems to be a good approximation of behavior driven by mainly basic need deprivation states and that is characterized by low levels of cognitive intervention.

Among the universally-shared needs, a further distinction relates to the underlying satiation properties they show Witt (2001; 2010). On the one hand, there are basic needs which follow homeostatic features, i.e., deprivation can be reduced relatively easily up to the temporary satiation point once rising income allows for a sufficient increase in the corresponding consumption expenditures per period of time. The motivation to consume is, then, temporarily reduced or removed. Satisfaction of these needs depends mainly on the intrinsic value of the corresponding goods and services. Examples are the homeostatic needs underlying to eating, drinking, sleeping, and the maintenance of body temperature. On the other hand, there are also basic needs where homeostatic features are absent, and where it is therefore difficult, if not impossible, to reduce the average deprivation to zero. Typically, these are needs whose satiation level is defined in relative terms, like the need for arousal and for social recognition.

Despite interpersonal sources of variance, which can be expected due to individual cognitive and conditioning learning processes, it can be conjectured, that shared innate needs exert some systematic effects on behavior, that are visible at the level of the population means, i.e., at the level of aggregate consumer expenditures. As needs differ with respect to the amount of spending that is necessary to reach satiation, this difference can be expected to become relevant with rising real income Witt $(2001 ; 2011)$. Being able to spend more, consumers should be able to approach the satiation level of some needs faster than the satiation level of other needs. Their consumption motivation is not equally upheld and their spending should thus not expand equally. Differences in the income elasticity of demand for the products that serve the different needs should express this differential satiation effect. A formal model of the differential satiation effects and its implications for Engel curves has recently been put forward by Lades (2013).

Taken together, the behavioral approach to consumption suggests connecting the differences in satiation patterns between innate needs with systematic changes in consumption expenditures when income rises. It is conjectured that, at the level of aggregate expenditure data, these differences translate into different income elasticities of demand for products or groups of goods and services that are likely to be consumed to serve those needs. The behavioral approach to consumption should thus be able to explain a good deal of the differences in the shapes of Engel's curves and thus in the income elasticities of the underlying goods and services.

A double-log specification of the Engel's function has been chosen in order to estimate the expenditure elasticity of households by using an economic status of households' head at work for each household by children per 
person. The data set were obtained from the Slovak Statistical office and consists of the yearly observations:

- money incomes of private household by economic status of household head at work per person and month $(€)$;

- money incomes of private household by children per person and month $(€)$;

- money expenditures of households by using and economic status of household head at work per person and month $(€)$;

- money expenditures of households by aim of using and number of children $(€)$.

The household Budget Survey of the Slovak Statistical office was used for the period 2004-2014. The use of the household level data offers the potential of richer dataset that may offer an additional insight into the underlying economic relationships.

\section{A Double-Log}

Specification has proven the most appropriate way of estimating the expenditure elasticity of demand; it generates more realistic expenditure elasticities. The general model can be written as follow:

$$
\ln w j=\alpha j+\beta j \ln y+\eta j
$$

where: $w j$ is the average annual per capita expenditure share for food group $j, \alpha j$, and $\beta j$ are the estimated coefficients, $y$ is the average total per capita income calculated as the average annual total per capita expenditure, and $\eta j$ is the disturbance term. As pointed out before, the derivation of the Engel's function assumes constant prices. Equation is estimated for each of the 13 food groups for each household by child and by economic status of household head. We have to include dummy variables.

We have supposed there are differences in the elasticity for each food group among several types of households.

\section{Households' Classification}

Analysis of the income elasticity was determined in 2,418 Slovak households. Different types of households were classified based on the economic status of the household head (household of employees, self-employed household, household of pensioners and others). For better orientation it is essential to characterize the household types as defined by the Statistical Office of the Slovak Republic: Economic status of household head was characterized by his/her employment status.

Employee: a person, who works for a public or private employer, and who receives compensation in the form of wage or salaries, including pensioners with income from employment and co-operative members.

Self-employed person: works in their own business, including pensioners with income from own business.

Pensioner: a person without job, who receives retired pension, with no income from job or business; in household could live also other persons without old-age pension.

Others: all persons, which were not included therein before (unemployed, maternity or paternity leave, students, etc.).

\section{Results and Discussion}

\subsection{Analysis of the Income Elasticity of Demand}

Quantity demanded sensitivity to changes in income, ceteris paribus, was measured by the coefficient of income elasticity. The income elasticity of demand is the ratio of the percentage change in quantity demanded product $X$ to percentage change in income, and shows how many percent will change the demand for product $X$ if there is 1 percent change in consumer income. For normal goods the income elasticity is positive. As we deepen our classification of goods to essential goods, the $1 \%$ change in consumer's income caused less than $1 \%$ change in demand for the goods. Because the share of the goods on a total income decreases, the average propensity to consume is decreasing and true: $0 \leq E i d \leq 1$.

Analysis of the income elasticity was investigated for each type of households by number of dependent children and for households by economic status of the household head.

From the Tab. 1 it could be identified that the calculated elasticity were highly significant. All food groups have explained variability over $90 \%$. Almost every elasticity reached the positive value, except these of meat and oils and fats. This means, that all the food groups within the interval $0 \leq \beta \leq 1$ are the Slovak households without children needs. $1 \%$ change in the consumer's income results in a change in demand for the good which is less than $1 \%$. 


\begin{tabular}{|c|c|c|c|c|c|c|c|c|c|c|c|c|c|c|c|c|}
\hline Tab. 1: & $\begin{array}{l}\text { El } \\
\text { in }\end{array}$ & $\begin{array}{l}\text { stic } \\
00\end{array}$ & $\begin{array}{l}y \text { of } \\
2014\end{array}$ & ous & holds & CC & $1 \mathrm{ch}$ & g to $n$ & mk & $\begin{array}{l}2 \text { chil } \\
\text { oseho }\end{array}$ & $\begin{array}{l}\text { d with } \\
\text { ren }\end{array}$ & n r & $r p$ & $\begin{array}{l}\text { rSOn a } \\
\text { Household } \\
\text { and more ch }\end{array}$ & $\begin{array}{l}\text { ith } \\
\text { Idren }\end{array}$ & 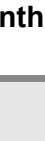 \\
\hline & $a$ & $\beta$ & Prob & R2 & $\mathrm{E}_{\mathrm{ID}}$ & $a$ & $\beta$ & $E_{1 D}$ & $a$ & $\beta$ & $E_{1 D}$ & $a$ & $\beta$ & $E_{1 D}$ & prob & R2 \\
\hline $\begin{array}{l}\text { Bread \& } \\
\text { cereals }\end{array}$ & -1.04 & 0.55 & $1.39 \mathrm{E}-15$ & 0.982 & $\begin{array}{l}\text { necessary } \\
\text { goods }\end{array}$ & -1.38 & 0.75 & $\begin{array}{l}\text { necessary } \\
\text { goods }\end{array}$ & -1.38 & 0.81 & $\begin{array}{l}\text { necessary } \\
\text { goods }\end{array}$ & -1.38 & 0.93 & $\begin{array}{l}\text { necessary } \\
\text { goods }\end{array}$ & $1.23 \mathrm{E}-17$ & 0.96 \\
\hline Meat & 1.28 & -0.08 & $7.67 \mathrm{E}-16$ & 0.983 & $\begin{array}{l}\text { inferior } \\
\text { goods }\end{array}$ & 0.43 & 0.37 & $\begin{array}{l}\text { necessary } \\
\text { goods }\end{array}$ & 0.43 & 0.26 & $\begin{array}{l}\text { necessary } \\
\text { goods }\end{array}$ & 0.43 & 0.22 & $\begin{array}{l}\text { necessary } \\
\text { goods }\end{array}$ & $1.77 \mathrm{E}-15$ & 0.93 \\
\hline Fish & -2.18 & 0.21 & 4.96E-18 & 0.991 & $\begin{array}{c}\text { necessary } \\
\text { goods }\end{array}$ & -2.48 & 0.5 & $\begin{array}{l}\text { necessary } \\
\text { goods }\end{array}$ & -2.48 & 0.4 & $\begin{array}{l}\text { necessary } \\
\text { goods }\end{array}$ & -2.48 & 0.35 & $\begin{array}{l}\text { necessary } \\
\text { goods }\end{array}$ & $2.24 \mathrm{E}-16$ & 0.94 \\
\hline $\begin{array}{l}\text { Milk, cheese \& } \\
\text { eggs }\end{array}$ & 0.06 & 0.29 & $9.93 \mathrm{E}-12$ & 0.949 & $\begin{array}{l}\text { necessary } \\
\text { goods }\end{array}$ & -0.77 & 0.55 & $\begin{array}{l}\text { necessary } \\
\text { goods }\end{array}$ & -0.77 & 0.54 & $\begin{array}{l}\text { necessary } \\
\text { goods }\end{array}$ & -0.77 & 0.54 & $\begin{array}{l}\text { necessary } \\
\text { goods }\end{array}$ & $7.07 \mathrm{E}-14$ & 0.91 \\
\hline Oil \& fats & 0.13 & -0.22 & $7.33 \mathrm{E}-14$ & 0.972 & $\begin{array}{l}\text { inferior } \\
\text { goods }\end{array}$ & -0.21 & 0.23 & $\begin{array}{l}\text { necessary } \\
\text { goods }\end{array}$ & -0.21 & 0.1 & $\begin{array}{l}\text { necessary } \\
\text { goods }\end{array}$ & -0.21 & 0.1 & $\begin{array}{l}\text { necessary } \\
\text { goods }\end{array}$ & $2.86 \mathrm{E}-09$ & 0.8 \\
\hline Fruits & -1.95 & 0.3 & $5.44 \mathrm{E}-13$ & 0.964 & $\begin{array}{l}\text { necessary } \\
\text { goods }\end{array}$ & -1.67 & 0.44 & $\begin{array}{l}\text { necessary } \\
\text { goods }\end{array}$ & -1.67 & 0.36 & $\begin{array}{l}\text { necessary } \\
\text { goods }\end{array}$ & -1.67 & 0.29 & $\begin{array}{c}\text { necessary } \\
\text { goods }\end{array}$ & $2.51 \mathrm{E}-12$ & 0.88 \\
\hline $\begin{array}{l}\text { Vegetables } \\
\text { incl. potatoes }\end{array}$ & -3.3 & 0.66 & $1.17 \mathrm{E}-10$ & 0.932 & $\begin{array}{l}\text { necessary } \\
\text { goods }\end{array}$ & -3.6 & 0.92 & $\begin{array}{l}\text { necessary } \\
\text { goods }\end{array}$ & -3.6 & 0.88 & $\begin{array}{l}\text { necessary } \\
\text { goods }\end{array}$ & -3.6 & 0.94 & $\begin{array}{l}\text { necessary } \\
\text { goods }\end{array}$ & $1.70 \mathrm{E}-11$ & 0.87 \\
\hline $\begin{array}{l}\text { Sugar, jam, } \\
\text { honey, } \\
\text { chocolate \& } \\
\text { confectionery }\end{array}$ & 0.19 & 0.01 & $6.01 \mathrm{E}-13$ & 0.964 & $\begin{array}{l}\text { necessary } \\
\text { goods }\end{array}$ & 0.23 & 0.2 & $\begin{array}{l}\text { necessary } \\
\text { goods }\end{array}$ & 0.23 & 0.14 & $\begin{array}{c}\text { necessary } \\
\text { goods }\end{array}$ & 0.23 & 0.1 & $\begin{array}{l}\text { necessary } \\
\text { goods }\end{array}$ & 1.25E-09 & 0.81 \\
\hline $\begin{array}{l}\text { Coffee, tea \& } \\
\text { cocoa }\end{array}$ & -3.11 & 0.5 & $2.48 \mathrm{E}-14$ & 0.975 & $\begin{array}{l}\text { necessary } \\
\text { goods }\end{array}$ & -3.22 & 0.7 & $\begin{array}{l}\text { necessary } \\
\text { goods }\end{array}$ & -3.22 & 0.67 & $\begin{array}{l}\text { necessary } \\
\text { goods }\end{array}$ & -3.22 & 0.66 & $\begin{array}{l}\text { necessary } \\
\text { goods }\end{array}$ & $1.52 \mathrm{E}-15$ & 0.93 \\
\hline $\begin{array}{l}\text { Mineral } \\
\text { waters, juices } \\
\& \text { other } \\
\text { non-alcoholic } \\
\text { drinks }\end{array}$ & -2.18 & 0.59 & $6.77 \mathrm{E}-11$ & 0.936 & $\begin{array}{l}\text { necessary } \\
\text { goods }\end{array}$ & -3.07 & 0.68 & $\begin{array}{l}\text { necessary } \\
\text { goods }\end{array}$ & -3.07 & 0.68 & $\begin{array}{l}\text { necessary } \\
\text { goods }\end{array}$ & -3.07 & 0.58 & $\begin{array}{l}\text { necessary } \\
\text { goods }\end{array}$ & $1.73 \mathrm{E}-20$ & 0.97 \\
\hline $\begin{array}{l}\text { Alcoholic } \\
\text { beverages \& } \\
\text { tobacco }\end{array}$ & -1.86 & 0.47 & $4.88 \mathrm{E}-14$ & 0.973 & $\begin{array}{l}\text { necessary } \\
\text { goods }\end{array}$ & -1.86 & 0.58 & $\begin{array}{l}\text { necessary } \\
\text { goods }\end{array}$ & -1.86 & 0.42 & $\begin{array}{l}\text { necessary } \\
\text { goods }\end{array}$ & -1.86 & 0.29 & $\begin{array}{c}\text { necessary } \\
\text { goods }\end{array}$ & $1.63 \mathrm{E}-16$ & 0.95 \\
\hline $\begin{array}{l}\text { Alcoholic } \\
\text { beverages }\end{array}$ & -2.38 & 0.35 & $7.13 \mathrm{E}-17$ & 0.987 & $\begin{array}{c}\text { necessary } \\
\text { goods }\end{array}$ & -2.47 & 0.58 & $\begin{array}{c}\text { necessary } \\
\text { goods }\end{array}$ & -2.47 & 0.54 & $\begin{array}{l}\text { necessary } \\
\text { goods }\end{array}$ & -2.47 & 0.46 & $\begin{array}{c}\text { necessary } \\
\text { goods }\end{array}$ & $9.65 \mathrm{E}-15$ & 0.92 \\
\hline
\end{tabular}

Source: own calculations

Legend: $\alpha$-intercept, $\beta$-regression coefficient, $E_{I D}$-income elasticity of demand, prob.-probability value, R2-coefficient of determination

The highest value of the elasticity was found in case of vegetables, including potatoes. If we have increased the revenue by $1 \%$, the demand changed by $0.66 \%$. Soft drinks, coffee, tea, cocoa, and mineral water have relatively similar levels of elasticity at the level of $0.5 \%$. Fish, milk, cheese, and eggs showed the elasticity around $0.2 \%$. The consumption of these products is relatively little affected by the change of income. We have focused on negative elasticity mainly. Very sensitive commodity was the meat. From a nutritional point of view this is an important food, and in financial terms, it represents one of the most expensive food for the Slovak households. This fact was indicates by the elasticity value $-0.08 .1 \%$ change in income will surely results in change of consumer preferences for meat by $-0.08 \%$. Fats \& oils have even more negative elasticity value, reaching $-0.22 \%$ only. In case of households without children the needs for goods such as meat, oil \& fats were only inferior, demand for them decreases with an increasing income.

Fig. 1 shows the differences in retirement elasticity of households according to number of children. There is a significant difference between households with children and households without them. The number of children per household is not the most important factor for a change in retirement elasticity.

The analysis of variance among the groups of households studied shows that the null hypothesis $\mathrm{H}_{0}$ cannot be rejected: All population 


\section{Fig. 1: Box plot of elasticity of households according to number of children}

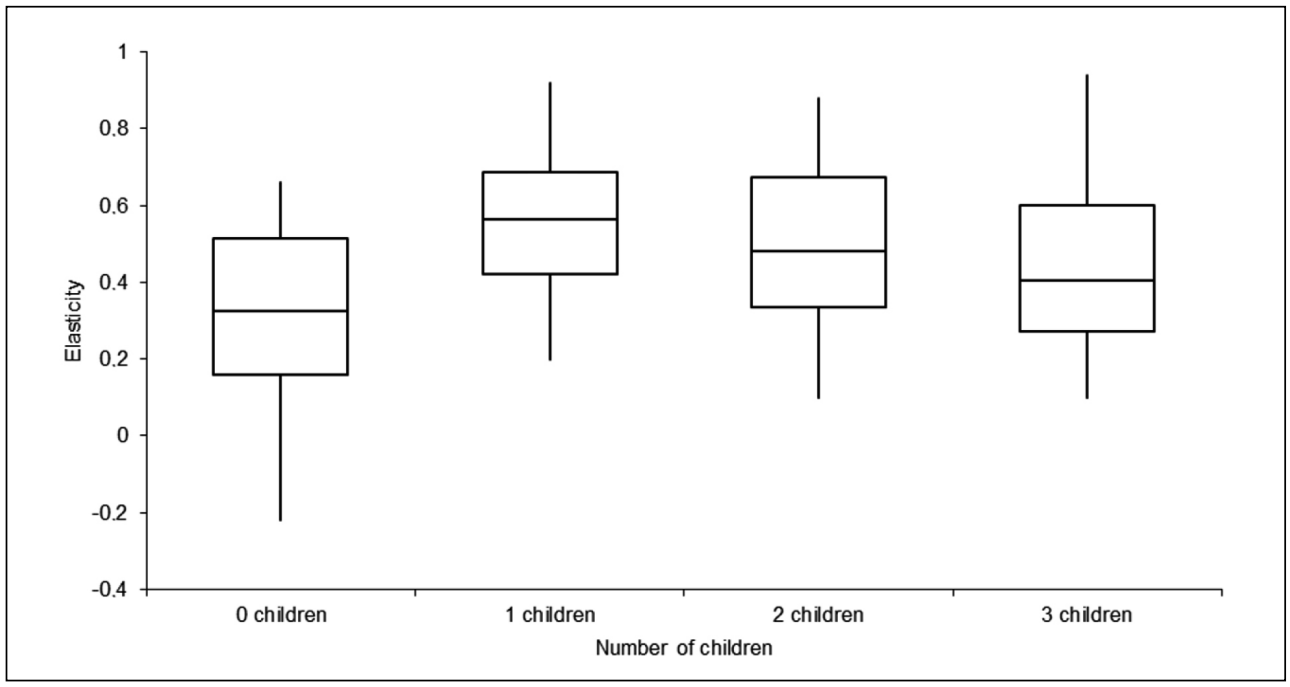

Source: own

with regard to elasticity is equal ( $p$-value $=$ 0.14738 ). Therefore, there is no statistically significant difference among the households according to number of children.

Analysis of the relationship between models of consumer demand based on micro and aggregate data were provided by Blundell et al. (1993). According to their findings it is important to establish the presence of nonlinearity in the micro-level Engel's curves and the need for interactions with householdspecific characteristics, since either of these would rule out simple linear aggregation. In our sample, pooled over 10 years, we have found strong evidence of both.

Similar to our result were the findings of the foodstuff model described by Chai and Moneta (2010), in which the prices of corn and fruits \& vegetables positively affect income; the prices of dairy products affects the income negatively. In the wage income model on the other side the elasticity of corn was the same as in previous models; the elasticity of dairy products was significantly negative, but smaller in absolute values ( -0.58 vs. -1.41 , and -1.10$)$; and the elasticity of fruits $\&$ vegetables was no longer statistically significant. There were minor differences in the estimates of the demand elasticity across the models.
Income elasticity was slightly above the levels for cheese \& giblets, and notably above the values for bovine (1.43), other cereals (1.37), and mutton (1.50). Income elasticity falls between 0.5 and unity for fish (0.56), bread $(0.64)$, eggs $(0.66)$, rice $(0.74)$, yogurt $(0.75)$, milk (0.79), poultry $(0.87)$, fats $(0.88)$, dough product (0.95), and oils (0.98). Our income elasticity for bread constitutes the lower limit of earlier estimates, which range from 0.65 to 0.85 , while income elasticities for meat, meat products, dairy products, and eggs were similar to those reported by Hes et al. (2008), Lades (2013), and Witt $(2001 ; 2011)$.

The estimation results indicate that the total per capita expenditure and the household size have significantly negative estimates in both groups of households. The estimate of remittances is positive and significant only in the group of rich households, so when the remittances increase, households above the poverty line increase their share of food consumption Narver (1990).

Households with 1 child has the highest value of the elasticity of vegetables including potatoes and bread and cereals. If we increased revenue by $1 \%$, the demand for vegetables increased by $0.92 \%$ and the demand for bread and cereals should be increased by $0.75 \%$. The lowest 
value of elasticity was shown in case of sugar and oils \& fats. From the observed results it is visible, in which food group will the households with 1 child obviously respond by increased consumption. The situation in households with 2 children was similar. The highest value of elasticity was again found in case of vegetables (0.88) and bread \& cereals (0.81). Changed consumers' behavior was noticed in case of confectionery, and oils \& fats. Higher income would results in lower change for goods such as meat $(0.26 \%)$ and fruits $(0.36 \%)$.

Behavioral pattern of households with 3 and more children according to the values of calculated elasticity is identical to the previously examined types. The highest elasticity was found again in vegetables (0.94) and bread \& cereals (0.93). Higher income in this type of households would cause lower change for goods such as meat $(0.22 \%)$ and fruits $(0.29 \%)$. Interestingly, these households would increase revenue by buying more cereals and vegetables, including potatoes, than meat and fishes.

Results of income elasticity in different household types, classified on the base of the economic status of the household head, processed in the Tab. 2 have showed, that the calculated elasticity was significant. All food groups reached variability over $80 \%$.

Households with employed household head reported positive elasticity in all food groups analyzed. Only in case of fruit, vegetables, coffee, tea \& cocoa, and alcoholic beverages, income elasticity overreached the value 1 (luxury goods). Households with employed head of household were more sensitive to the food groups: fruits; vegetables; coffee, tea \& cocoa; and alcoholic beverages. The lowest value of reported elasticity (0.58) was found in case of mineral water and soft drinks.

\begin{tabular}{|c|c|c|c|c|c|c|c|c|c|c|c|c|c|c|}
\hline \multirow[t]{3}{*}{ Tab. 2: } & $\begin{array}{l}\text { yo } \\
\text { on }\end{array}$ & $\begin{array}{l}\text { nol } \\
\text { nd }\end{array}$ & $\begin{array}{l}\text { sehol } \\
\text { nonth }\end{array}$ & $\begin{array}{l}\text { ac } \\
2 \mathrm{C}\end{array}$ & $\begin{array}{l}\text { jor } \\
04\end{array}$ & $\begin{array}{l}\text { ng to } \\
014 \text { (in }\end{array}$ & $\begin{array}{l}\text { Co } \\
€)\end{array}$ & on & stat & & & ehold & head & \\
\hline & \multicolumn{3}{|c|}{ Household of employee } & \multicolumn{3}{|c|}{$\begin{array}{l}\text { Household } \\
\text { of self-employed }\end{array}$} & \multicolumn{3}{|c|}{ Household of pensioner } & \multicolumn{5}{|c|}{ Other households } \\
\hline & $a$ & $\beta$ & $E_{1 D}$ & $a$ & $\beta$ & $E_{I D}$ & $\alpha$ & $\beta$ & $E_{1 D}$ & $a$ & $\beta$ & $E_{I D}$ & prob. & R2 \\
\hline Bread \& cereals & -1.39 & 0.85 & $\begin{array}{l}\text { necessary } \\
\text { goods }\end{array}$ & -1.39 & 0.81 & $\begin{array}{l}\text { necessary } \\
\text { goods }\end{array}$ & -1.39 & 1.04 & $\begin{array}{l}\text { luxury } \\
\text { goods }\end{array}$ & -1.39 & 1.02 & $\begin{array}{l}\text { luxury } \\
\text { goods }\end{array}$ & $2.71 \mathrm{E}-20$ & 0.94 \\
\hline Meat & 0.27 & 0.7 & $\begin{array}{l}\text { necessary } \\
\text { goods }\end{array}$ & 0.27 & 0.7 & $\begin{array}{l}\text { necessary } \\
\text { goods }\end{array}$ & 0.27 & 1.03 & $\begin{array}{l}\text { luxury } \\
\text { goods }\end{array}$ & 0.27 & 0.81 & $\begin{array}{l}\text { necessary } \\
\text { goods }\end{array}$ & $6.76 \mathrm{E}-18$ & 0.91 \\
\hline Fish & -3.43 & 0.94 & $\begin{array}{l}\text { necessary } \\
\text { goods }\end{array}$ & -3.43 & 0.92 & $\begin{array}{l}\text { necessary } \\
\text { goods }\end{array}$ & -3.43 & 1.2 & $\begin{array}{l}\text { luxury } \\
\text { goods }\end{array}$ & -3.43 & 1.03 & $\begin{array}{l}\text { luxury } \\
\text { goods }\end{array}$ & $6.73 \mathrm{E}-16$ & 0.88 \\
\hline Milk, cheese \& eggs & -0.64 & 0.7 & $\begin{array}{l}\text { necessary } \\
\text { goods }\end{array}$ & -0.64 & 0.69 & $\begin{array}{l}\text { necessary } \\
\text { goods }\end{array}$ & -0.64 & 0.91 & $\begin{array}{l}\text { necessary } \\
\text { goods }\end{array}$ & -0.64 & 0.74 & $\begin{array}{l}\text { necessary } \\
\text { goods }\end{array}$ & $2.03 \mathrm{E}-20$ & 0.94 \\
\hline Oil \& fats & -1.17 & 0.82 & $\begin{array}{l}\text { necessary } \\
\text { goods }\end{array}$ & -1.17 & 0.78 & $\begin{array}{l}\text { necessary } \\
\text { goods }\end{array}$ & -1.17 & 1.3 & $\begin{array}{l}\text { luxury } \\
\text { goods }\end{array}$ & -1.17 & 0.97 & $\begin{array}{l}\text { necessary } \\
\text { goods }\end{array}$ & $4.72 \mathrm{E}-21$ & 0.94 \\
\hline Fruit & -3.02 & 1.01 & $\begin{array}{l}\text { luxury } \\
\text { goods }\end{array}$ & -3.02 & 0.99 & $\begin{array}{l}\text { necessary } \\
\text { goods }\end{array}$ & -3.02 & 1.31 & $\begin{array}{l}\text { luxury } \\
\text { goods }\end{array}$ & -3.02 & 1.07 & $\begin{array}{l}\text { luxury } \\
\text { goods }\end{array}$ & $3.73 \mathrm{E}-18$ & 0.91 \\
\hline Vegetable incl. potatoes & -4.03 & 1.23 & $\begin{array}{l}\text { luxury } \\
\text { goods }\end{array}$ & -4.03 & 1.2 & $\begin{array}{l}\text { luxury } \\
\text { goods }\end{array}$ & -4.03 & 1.54 & $\begin{array}{l}\text { luxury } \\
\text { goods }\end{array}$ & -4.03 & 1.49 & $\begin{array}{l}\text { luxury } \\
\text { goods }\end{array}$ & $4.67 \mathrm{E}-15$ & 0.87 \\
\hline $\begin{array}{l}\text { Sugar, jam, honey, chocolate \& } \\
\text { confectionery }\end{array}$ & -0.68 & 0.67 & $\begin{array}{l}\text { necessary } \\
\text { goods }\end{array}$ & -0.68 & 0.63 & $\begin{array}{l}\text { necessary } \\
\text { goods }\end{array}$ & -0.68 & 0,95 & $\begin{array}{l}\text { necessary } \\
\text { goods }\end{array}$ & -0.68 & 0.63 & $\begin{array}{l}\text { necessary } \\
\text { goods }\end{array}$ & $6.48 \mathrm{E}-18$ & 0.91 \\
\hline Coffee, tea \& cocoa & -3.75 & 1.11 & $\begin{array}{l}\text { luxury } \\
\text { goods }\end{array}$ & -3.75 & 1.06 & $\begin{array}{l}\text { luxury } \\
\text { goods }\end{array}$ & -3.75 & 1,43 & $\begin{array}{l}\text { luxury } \\
\text { goods }\end{array}$ & -3.75 & 1.26 & $\begin{array}{l}\text { luxury } \\
\text { goods }\end{array}$ & $6.02 \mathrm{E}-23$ & 0.95 \\
\hline $\begin{array}{l}\text { Mineral waters, juices \& other } \\
\text { non-alcoholic drinks }\end{array}$ & -2.33 & 0.58 & $\begin{array}{l}\text { necessary } \\
\text { goods }\end{array}$ & -2.33 & 0.61 & $\begin{array}{l}\text { necessary } \\
\text { goods }\end{array}$ & -2.33 & 0,55 & $\begin{array}{l}\text { necessary } \\
\text { goods }\end{array}$ & -2.33 & 0.52 & $\begin{array}{l}\text { necessary } \\
\text { goods }\end{array}$ & $2.48 \mathrm{E}-18$ & 0.92 \\
\hline Alcoholic beverages \& tobacco & -2.56 & 0.82 & $\begin{array}{l}\text { necessary } \\
\text { goods }\end{array}$ & -2.56 & 0.81 & $\begin{array}{l}\text { necessary } \\
\text { goods }\end{array}$ & -2.56 & 0,83 & $\begin{array}{l}\text { necessary } \\
\text { goods }\end{array}$ & -2.56 & 1.02 & $\begin{array}{l}\text { luxury } \\
\text { goods }\end{array}$ & $1.04 \mathrm{E}-12$ & 0.82 \\
\hline Alcoholic beverages & -3.64 & 1.11 & $\begin{array}{l}\text { luxury } \\
\text { goods }\end{array}$ & -3.64 & 1.08 & $\begin{array}{l}\text { luxury } \\
\text { goods }\end{array}$ & -3.64 & 1,39 & $\begin{array}{l}\text { luxury } \\
\text { goods }\end{array}$ & -3.64 & 1.13 & $\begin{array}{l}\text { luxury } \\
\text { goods }\end{array}$ & $1.78 \mathrm{E}-23$ & 0.96 \\
\hline
\end{tabular}

Source: own calculations

Legend: $\alpha$-intercept, $\beta$-regression coefficient, EID-income elasticity of demand, prob.-probability value, R2-coefficient of determination 
Households of self-employed head of household represents the engine of the Slovak economy and their performance contributed significantly to the GDP of the Slovak Republic. In terms of consumer behavior we have found, that income elasticity in case of vegetables, alcoholic beverages, coffee, tea \& cocoa put these food groups to the category of luxury goods. The lowest value of elasticity was found in food group of mineral water (0.61) and confectionery (0.63).

Income elasticity in 1,413 examined households of pensioners indicated, that almost all of the food groups belong to the luxury items. In all types of households examined on the base of their economic status we have found, that the elasticity in the group of alcoholic beverages overreached the value 1 (so the alcoholic beverages belongs to the luxury items). However, if we looked at the group of alcoholic beverages \& tobacco, elasticity was reduced to the level of necessary goods. This clearly identifies the consumption of cigarettes.

In other 392 examined households even the bread \& cereals; fish; fruit; vegetables, as well as coffee, tea \& cocoa; and alcoholic beverages $\&$ tobacco were considered as luxury goods.
Fig. 2 shows the differences in retirement elasticity of households according to economic status. The households of employed and self-employed ones do not show significant differences in retirement elasticity. On the contrary, the households of pensioners show most significant differences in retirement elasticity in comparison with other groups of households studied.

The analysis of variance among the groups of households studied shows that the null hypothesis $\mathrm{H}_{0}$ is rejected: All population with regard to elasticity is equal ( $p$-value $=0.03949$ ). Therefore, there is a statistically significant difference among the households according to economic status. These differences can be used when working on business strategy.

\section{Conclusions}

Analysis of income elasticity using Engel's model clearly demonstrated negative correlation of food expenditure in Slovak households and the number of children in all food groups of the consumer basket classified as necessary goods.

The examination of the households classified by an economic activity of their head has shown that in the households with an employed

\section{Fig. 2: Box plot of elasticity of households according to economic status}

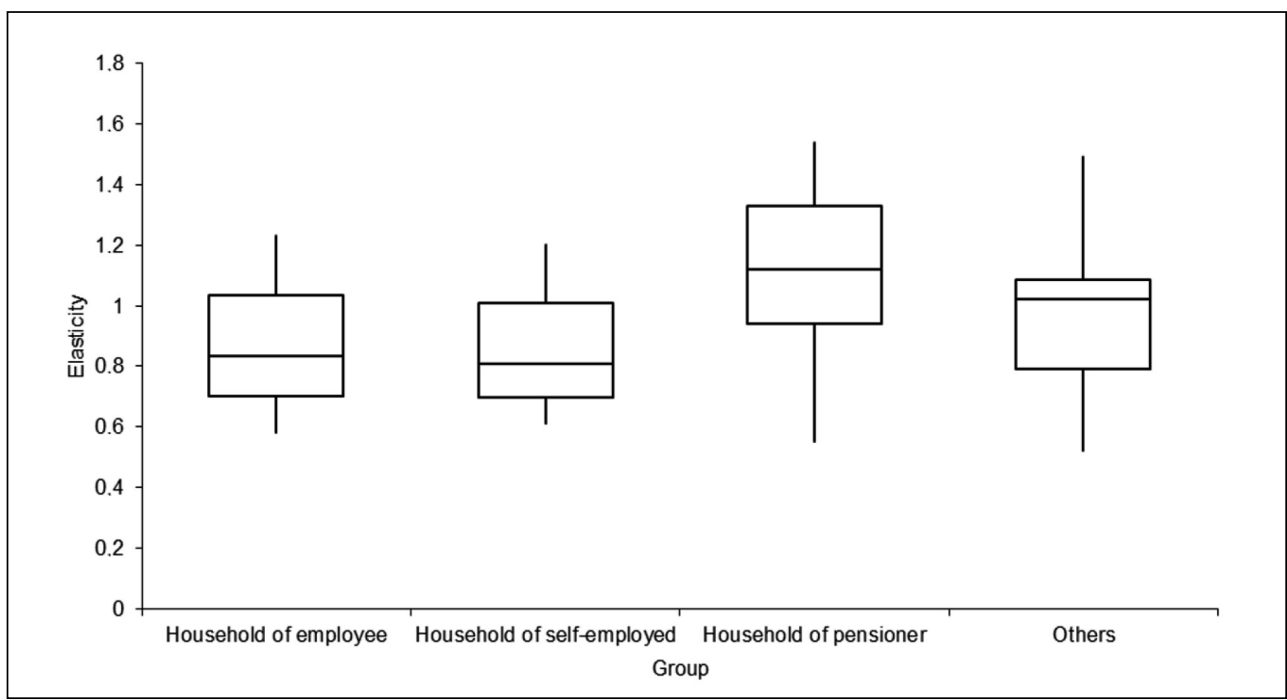


household's head, there was certain food, such as fruits, vegetables, coffee, tea and alcohol beverages, classified as luxury goods. Even in the households with a self-employed head, vegetables, coffee \& tea, and alcohol beverages were considered to be luxury items (only 1 food group less than in the households with an employed household's head). The households of retirees have almost all food groups within the luxury category except milk \& eggs, sweeteners, non-alcoholic, and alcoholic drinks \& tobacco. The households without children have meat and fats \& oils included in the category of inferior goods. However, other types of households according to number of children considered all types of food in the consumer basket to be necessary goods.

\section{References}

Aguirre Sotelo, J. A. M., \& Block, W. E. (2014). Indifference Curve Analysis: The Correct and the Incorrect. Oeconomia Copernicana, 5(4), 7-43. doi:10.12775/OeC.2014.025.

Andrejovska, A., \& Banociova, A. (2014). Payment discipline in business environment. Procedia Economics and Finance, 15, $1217-$ 1224. doi:10.1016/S2212-5671(14)00581-4.

Becerra Alonso, D., Androniceanu, A., \& Georgescu, I. (2016). Sensitivity and vulnerability of European countries in time of crisis based on a new approach to data clustering and curvilinear analysis. Administration and Public Management Review, 14(27), 46-61.

Bacik, R., Gavurova, B., \& Fedorko, I. (2015). The Analysis of the Impact of Selected Marketing Communication Factors on the Online Consumer Behavior. Journal of Applied Economic Sciences, 10(7), 999-1004.

Benda Prokeinova, R., \& Hanova, M. (2016). Modelling consumer's behaviour of the meat consumption in Slovakia. Agricultural Economics (Czech Republic), 62(5), 235-245. doi:10.17221/33/2015-AGRICECON.

Blundell, R., Pashardes, P., \& Weber, G. (1993). What Do We Learn About Consumer Demand Patterns from Micro Data? American Economic Review, 83(3), 570-597.

Chai, A., \& Moneta, A. (2010). Retrospectives: Engel curves. Journal of Economic Perspectives, 24(1), 225-240. doi:10.1257/jep.24.1.225.

Czarniewski, S. (2014). Building Customer Loyalty on the Polish Market. Economics \& Sociology, 7(3), 208-222 doi:10.14254/2071789X.2014/7-3/16.
Deaton, A. S., \& Muellbauer, J. (1980). An Almost Ideal Demand System. American Economic Review, 70(3), 312-336.

Drucker, P. F. (1954). Concept of the Corporation. USA: John Da.

Dúbravská, M., Mura, L., Kotulič, R., \& Novotný, J. (2015). Internationalization of Entrepreneurship - Motivating Factors: Case Study of the Slovak Republic. Acta Polytechnica Hungarica, 12(5), 121-133. doi:10.12700/APH.12.5.2015.5.7.

Engel, E. (1857). Die Produktions- und Consumptionsverhältnisse des Königreichs Sachsen. Bulletin de Institut International de Statistique, 9, 1-54.

Engel, E. (1895). Die Lebenskosten belgischer Arbeiterfamilien früher und jetzt. Bulletin de l'Institut International de Statistique, 9, 1-124.

Gavurová, B., Vagasova, T., \& Kovac, V. (2016). Competitiveness Assessment of Slovak Republic Regions. European Financial System 2016: Proceedings of the 13th International Scientific Conference, 175.

Gombos, G., Kiss, A., \& Zvara, Z. (2016). Performance Analysis of a Cluster Management System with Stress Cases. Acta Polytechnica Hungarica, 13(2), 77-95. doi:10.12700/ APH.13.2.2016.2.5.

Grzega, U. (2015). Changes in consumption in Poland in the period of transformation. Journal of International Studies, 8(3), 152-163. doi:10.14254/2071-8330.2015/8-3/12.

Hayat, N., Hussain, A., \& Yousaf, $H$. (2016). Food demand in Pakistan: Analysis and projections. South Asia Economic Journal, 17(1), 94-113. doi:10.1177/1391561415621826.

Härdle, W., \& Jerison, H. (1991). Crosssection Engel Curves over Time. Recherches Economiques de Louvain, 57, 1525-1549.

Heikkinen, T. (2015). (De)growth and welfare in an equilibrium model with heterogeneous consumers. Ecological Economics, 116, 330-340. doi:10.1016/j.ecolecon.2015.05.005.

Herrnstein, R. J. (1997). The Matching Law. Cambridge, MA: Harvard University Press.

Hes, A., Šálková Regnerová, M., Pickar, M., Pavlů, D., Soukup, A., Turčínková, M., \& Drnzíková, T. (2008). Chování spotrebitele při nákupu potravin. Praha: Alfa Nakladatelství.

Hildenbrand, W. (1994). Market Demand: Theory and Empirical Evidence. Princeton: Princeton University Press.

Horáková, M. (2015). Consumer Behavior of College Students in the Czech Republic. 
Journal of Competitiveness, 7(4), 68-85. doi:10.7441/joc.2015.04.05.

Kahneman, D., Wakker, P. P., \& Sarin, R. (1997). Back to Bentham? Explorations of experienced utility. The Quarterly Journal of Economics, 112(2), 375-405. doi:10.1162/003355397555235.

Kohli, A. K., \& Jaworski, B. J. (1990). Market orientation: The construct, research propositions and managerial implications. Journal of Marketing, 54(2), 1-18. doi:10.2307/1251866.

Kotler, P., \& Armstrong, G. (2004). Marketing. Praha: Grada Publishing.

Koudelka, J. (2005). Segmentujeme spotrebni trhy. Praha: Professional Publishing, 2005.

Kramoliš, J., \& Drabková, M. (2012). Product scale promoting by product placement in the Czech Republic. Innovation and Sustainable Competitive Advantage: From Regional Development to World Economies - Proceedings of the 18th International Business Information Management Association Conference, 4, 1971-1982.

Kramoliš, J., \& Kopečková, M. (2014). Characteristics of an insert product placement as a part of marketing communication. Acta Universitatis Agriculturae Et Silviculturae Mendelianae Brunensis, 62(4), 659-666. doi:10.11118/actaun201462040659.

Krishna, A., \& Schwarz, N. (2014). Sensory marketing, embodiment, and grounded cognition: A review and introduction. Journal of Consumer Psychology, 24(2), 159-168. doi:10.1016/j.jcps.2013.12.006.

Lades, L. K. (2013). Explaining shapes of Engel curves: the impact of differential satiation dynamics on consumer behavior. Journal of Evolutionary Economics, 23(5), 1023-1045. doi:10.1007/s00191-013-0324-6.

Lewbel, A. (1993). The Rank of Demand Systems: Theory and Nonparametric Estimation. Econometrica, 59, 711-730. doi:10.2307/2938225.

Lewbel, A. (2008). Engel curve. In S. N. Durlauf, \& L. E. Blume (Eds.), The New Palgrave Dictionary of Economics (pp. 55-58). Basingstoke: Palgrave Macmillan.

Manzini, P., \& Mariotti, M. (2014). Stochastic Choice and Consideration Sets. Econometrica 82(3), 1153-1176. doi:10.3982/ECTA10575.

Matějka, F., \& McKay, A. (2015). Rational inattention to discrete choices: A new foundation for the multinomial logit model.
American Economic Review, 105(1), 272-298. doi:10.1257/aer.20130047.

Michalski, G. (2008). Value-based inventory management. Romanian Journal of Economic Forecasting, 9(1), 82-90.

Narver, J. C., Slater, S. F. (1990). The effect of a market orientation on business profitability. Journal of Marketing, 54(4), 20-35.

Novotný, J., \& Duspiva, P. (2014). Faktory ovlivňujíci kupní chování spotřebitelů a jejich význam pro podniky. E\&M Ekonomie a Management, 17(1), 152-166. doi:10.15240/ tul/001/2014-1-012.

Pérez, A., García de los Salmones, M. M., \& Rodríguez del Bosque, I. (2013). The effect of corporate associations on consumer behaviour. European Journal of Marketing, 47(1), 218-238. doi:10.1108/03090561311285529.

Piqueras-Fiszman, B., \& Jaeger, S. R. (2016). Consumer segmentation as a means to investigate emotional associations to meals. Appetite, 105(October), 249-258. doi:10.1016/j. appet.2016.05.034.

Prais, S. J., \& Houthakker, H. S. (1955). The Analysis of Family Budgets. Cambridge: Cambridge University Press.

Raisova, M., \& Durcova, J. (2014). Economic growth-supply and demand perspective. Procedia Economics and Finance, 15, 184-191. doi:10.1016/S2212-5671(14)00476-6.

Rypakova, M., Moravcikova, K., \& Krizanova, A. (2015). Online Customer Behaviour. Marketing Identity: Digital Life, Pt II, 233-246.

Saak, A. E. (2016). Optimal provision of information about consumption choices in the presence of a cognitive constraint. Economics Letters, 145(August), 25-28. doi:10.1016/j. econlet.2016.05.010.

Solomon, M. R., Marshall, G. W., \& Stuart, E. W. (2006). Marketing očima svetových marketing manažerů. Brno: Computer Press.

Šoltés, V., \& Gavurová, B. (2014). The Functionality Comparison of the Health Care Systems by the Analytical Hierarchy Process Method. E\&M Ekonomie a Management, 17(3), 100-118. doi:10.15240/tul/001/2014-3-009.

Šrédl, K., Soukup, A., \& Severová, L. (2013). Models of Consumer's Choice. E\&M Ekonomie a Management, 16(2), 4-9.

Staddon, J. E. R., \& Cerutti, D. T. (2003). Operant conditioning. Annual Review of Psychology, 54, 115-144. doi:10.1146/annurev. psych.54.101601.145124. 


\section{Ekonomie}

Statistical Office of SR. (2014). Household's income and expenditure. Retrieved October 3, 2015, from http://www. statistics.sk/pls/elisw/Metalnfo.explorer? $o b j=42 \& \mathrm{cmd}=g o \& s=1002 \& s s o=2 \& s o=40$.

Stávková, J. (Ed.). (2006). Trendy spotřebitelského chování. Brno: Mendelova zemědělská a lesnická univerzita.

Subramanyam, E. S., \& Kumaraswamy, S. (1981). EOQ formula under varying marketing policies and conditions. AllE Transactions, 13(4), 312-314.

Virglerova, Z., Dobes, K., \& Vojtovic, S. (2016). The Perception of the States Influence on its Business Environment in the SMEs from Czech Republic. Administration and Public Management Review, 14(26), 78-96.

Ulubasoglu, M., Mallick, D., Wadud, M., Hone, P., \& Haszler, H. (2016). Food demand elasticities for Australia. Australian Journal of Agricultural and Resource Economics, 60(2), 177-195. doi:10.1111/1467-8489.12111.

Wanninayake, W.M.C. Bandara (2014). Consumer Decision-Making Styles and Local Brand Biasness: Exploration in the Czech Republic. Journal of Competitiveness, 6(1), 3-18. doi:10.7441/joc.2014.01.01.

Witt, U. (2001). Learning to consume a theory of wants and the growth of demand. Journal of Evolutionary Economics, 11(1), 23-36. doi:10.1007/PL00003851.

Witt, U. (2008). What is specific about evolutionary economics? Journal of Evolutionary Economics, 18(5), 547-575. doi:10.1007/ s00191-008-0107-7.

Witt, U. (2010). Symbolic consumption and the social construction of product characteristics Structural Change and Economic Dynamics, 21(1), 17-25. doi:10.1016/j.strueco.2009.11.008.

Witt, U. (2011). The dynamics of consumer behavior and the transition to sustainable consumption patterns. Environmental Innovation and Societal Transitions, 1(1), 109-114. doi:10.1016/j.eist.2011.03.001.

Working, H. (1943). Statistical Laws of Family Expenditure. Journal of the American Statistical Association, 38, 43-56.

Ing. Renata Benda-Prokeinová, PhD. Slovak University of Agriculture in Nitra Faculty of Economics and Management Department of Statistics and Operation Research renata.prokeinova@uniag.sk

Ing. Kamil Dobeš, Ph.D. Tomas Bata University in Zlín Faculty of Management and Economics Department of Economics dobes@fame.utb.cz

doc. PhDr. Ing. Ladislav Mura, PhD. Pan-European University in Bratislava Faculty of Economics and Business Department of International Entrepreneurship ladislav.mura@gmail.com

doc. Ing. MVDr. Ján Buleca, PhD. Technical University of Košice Faculty of Economics Department of Finance jan.buleca@tuke.sk 


\section{Abstract}

\section{ENGEL'S APPROACH AS A TOOL FOR ESTIMATING CONSUMER BEHAVIOUR}

\section{Renata Benda-Prokeinová, Kamil Dobeš, Ladislav Mura, Ján Buleca}

Engel's approach to consumption plays an important role in theoretical economics. There is thus strong empirical and theoretical interest to analyze the cross-section Engel function of real populations. A prerequisite of any economic interpretation is a reasonable estimation of these curves from given cross-section data containing households' expenditures and income. In submitted paper the Engel curves computation was applied on the Slovak household's income and expenditure. A double-log specification of the Engel's function has been chosen in order to estimate the expenditure elasticity of households by using an economic status of households' head at work for each household by children per person. The household Budget Survey of the Slovak Statistical office was used for the period 2004-2014. Analysis of income elasticity demonstrated negative correlation of food expenditure in Slovak households and the number of children in all food groups of the consumer basket classified as necessary goods. Examination of the households based on the economic activity of their head (employee, self-employed, retired, and others) showed differences in availability of various food groups for the households (inferior, necessary, luxury goods). Increased amount of food groups were included within the luxury category in following order: the households with self-employed head, employed household head, and retirees. Households without children have meat and fats \& oils included in the category inferior goods, other types of households according to the number of children considered all types of food in the consumer basket as necessary goods. Results provide deeper knowledge about consumers' behavior of Slovak households.

Key Words: Engel curve, food consumption, household, income elasticity.

JEL Classification: D03, D11, D12.

DOI: 10.15240/tul/001/2017-2-002 